\title{
Persistent Activation of cAMP-Dependent Protein Kinase by Regulated Proteolysis Suggests a Neuron-Specific Function of the Ubiquitin System in Aplysia
}

\author{
Daniel G. Chain, Ashok N. Hegde, Naoki Yamamoto, Bo Liu-Marsh, and James H. Schwartz \\ Center for Neurobiology and Behavior, Columbia University College of Physicians and Surgeons, New York, New \\ York 10032
}

In response to the facilitating neurotransmitter serotonin (5-HT), the cAMP-dependent protein kinase (PKA) acquires a special mnemonic characteristic in Ap/ysia sensory neurons. PKA becomes persistently activated at basal CAMP concentrations owing to a decreased regulatory $(R)$ to catalytic (C) subunit ratio. We previously implicated ubiquitinmediated proteolysis in this selective loss of $\mathbf{R}$. Here we show that ubiquitin (Ub), Ub-conjugates and proteasomes are present in cell bodies, axon, neuropil and nerve terminals of Aplysia neurons. Because $\mathbf{R}$ subunits are not decreased in muscle exposed to 5-HT, comparison of the two tissues provides a tractable approach to determine how the Ub pathway is regulated. We compared the structure of M1, the muscle-specific $R$ isoform, to that of N4, a major neuronal $\mathbf{R}$ isoform, to rule out the possibility that the differences in their stability result from differences in structure. We present evidence that N4 and M1 are encoded by identical transcripts; they also behave similarly as protein substrates for the Ub pathway in extracts of the two tissues. Nervous tissue contains 20 -times more free $\mathrm{Ub}$, but we present evidence that the susceptibility of $\mathbf{R}$ subunits to degradation in neurons relative to muscle results from the greater capacity of neurons to degrade ubiquitinated proteins through the proteasome. Thus, factors that regulate the activity of proteasomes could underlie the enhanced degradation of $\mathbf{R}$ subunits in long-term sensitization.

[Key words: Aplysia, cAMP-dependent protein kinase, memory, persistent protein kinase, proteasome, protein degradation, ubiquitin]

In sensory-to-motor neuron synapses in Aplysia, the cAMP-dependent protein kinase (PKA) plays an important role in the presynaptic facilitation that underlies both short-term and longterm sensitization of defensive reflexes (reviewed by Kandel and Schwartz, 1982; Bailey and Kandel, 1993; Byrne et al., 1993). Bridging the short- and the long-term processes is a persistent

Received Jan. 31, 1995; revised July 14, 1995; accepted July 19, 1995.

We thank Hagan Bayley, Aaron Ciechanover, Alfred L. Goldberg, Avram Herstıko, and René Hen for their helpful comments and suggestions during the preparation of the manuscript. Fluorometric endopeptidase assays were performed in Dr. Goldberg's laboratory in the Department of Physiology at Harvard Medical School. This work was supported by Rescarch Grant NS29255 from the National Institutes of Health. J.H.S. is supported by Research Scientist Award MH0092I from the National Institute of Mental Health.

Correspondence should be addressed to Dr. James H. Schwartz, Center for Neurobiology and Behavior, 722 West 168 th Street, New York, NY 10032.

Copyright $(\mathcal{C} 1995$ Society for Neuroscience $0270-6474 / 95 / 157592-12 \$ 05.00 / 0$ increase in PKA-catalyzed protein phosphorylation in all regions of sensory neurons (Greenberg et al., 1987: Sweatt and Kandel, 1989). This phosphorylation is responsible for many of the changes in presynaptic membrane conductance, gene expression and synaptic growth that produce the enduring presynaptic facilitation underlying long-tern behavioral sensitization.

PKA is a heterotetramer composed of two catalytic (C) and two regulatory $(\mathrm{R})$ subunits (Taylor et al,, 1990) that usually are present in equimolar amounts (Hofmann et al., 1977). Aplysia nervous tissue contains at least five distinct $\mathrm{R}$ isoforms (Palazzolo et al., 1989; Cheley et al., 1994). The isoforms of the N4 family, homologs of vertebrate $\mathrm{R}_{\mathrm{I}}$ (Bergold et al., 1992) are decreased in long-term facilitation with no change in $C$, and this results in a persistently active kinase. The decrease in $\mathrm{R}$ can be produced by behavioral training (Greenberg et al., 1987: Schwartz and Greenberg, 1989) or by treatment of isolated intact ganglia with serotonin (5-HT) (Bergold et al., 1990), protocols that elevate intracellular cAMP concentrations for about $2 \mathrm{hr}$. PKA remains active, however, for at least $24 \mathrm{hr}$. This downregulation of all the major $\mathrm{R}$ subunits depends on new protein synthesis (Bergold et al., 1990), but no change in amounts of transcript is evident for either $\mathrm{R}$ or $\mathrm{C}$, suggesting that the mechanism by which $\mathrm{R}$ subunits are diminished is mediated by regulated proteolysis (Bergold et al., 1992).

The ubiquitin (Ub) pathway selectively degrades proteins in eukaryotic cells (reviewed by Finley and Chau, 1991; Hershko and Ciechanover, 1992; Rechsteiner et al., 1993; Ciechanover and Schwartz, 1994; Goldberg, 1995). Hegde et al. (1993) showed that Ub-mediated proteolysis degrades $\mathrm{R}$ subunits in Aplysia nervous tissue and postulated that this pathway is a molecular mechanism underlying long-term synaptic plasticity. We presume that the mechanism by which the kinase becomes persistently activated operates at synapses, and therefore we now examine the regional distribution of $\mathrm{Ub}, \mathrm{Ub}$-conjugates and proteasomes in Aplysia neurons. In addition, we attempt to identify limiting steps in the Ub system that might be sites for regulation. Bergold et al. (1990) found that the susceptibility of $\mathrm{R}$ to degradation differs markedly between neurons and muscle: while exposure to 5-HT evokes even higher concentrations of cAMP in muscle than in the sensory neurons, M1, the muscle R isoform, is stable even after prolonged elevation of cAMP. The difference in stability of $\mathrm{R}$ subunits in these tissues allows us to approach experimentally the question of how the degradation of $\mathrm{R}$ might be regulated: are there critical differences between the structures of $\mathrm{R}$ subunits in neurons and muscle, or is the $\mathrm{Ub}$ system specialized in neurons? 


\section{Materials and Methods}

Antibodies. A polyclonal anti-bovine Ub antibody was from Sigma (St. Louis, MO). Alkaline phosphatase-conjugated anti-rabbit IgG and antimouse IgG were from Promega (Madison, WI). A monoclonal antibody (MAb 7A11), raised against a subunit of human proteasome $(\mathrm{p} 27 \mathrm{~K})$, was from Organon (Turnhout, Belgium). We raised and affinity-purified the following bovine serum albumin-conjugated peptide antibodies in New Zealand White rabbits from Hare Marland (Hewitt, NJ) using Hunter's Titre Max adjuvant (Cyt Rex, Norcross, GA): AbN4-PEST, with a peptide, SKSATPPSDEKEEDMSSTPPQMH-amide, corresponding to the sequence between residues 63 and 85 of N4 (Bergold et al., 1992); and Ab-9410 against p28K, a subunit of Aplysia proteasome with the peptide LEANSFLEK-amide (see Results). The N4 peptide was synthesized by the Columbia University Biopolymer Facility, and $\mathrm{p} 28 \mathrm{~K}$ by Tana (Houston, TX). We also raised an antibody against recombinant N4 expressed in Escherichia coli (Bergold et al., 1992). A polyclonal antibody to recombinant Aplysia synaptotagmin was provided by $\mathrm{E}$. Kandel.

Animals. Aplysia californica weighing $70-100 \mathrm{gm}$ were raised at the Mariculture Resource Facility of the University of Miami, FL. Cell bodies and neuropil were obtained from ganglia of whole central nervous tissue by manual dissection of the connective tissue sheath and other regions (Schwartz and Swanson, 1987). Axoplasm was extruded from pleural-abdominal connectives by gentle rolling as described by Ambron et al. (1981). Synaptosomes were prepared by two-step sucrose-gradient differential centrifugation (Chin et al., 1989). Synaptotagmin immunoreactivity identified fractions enriched in synaptosomes. The accessory radula closer (ARC) muscle was dissected from fresh buccal mass, a muscular feeding organ. Recombinant N4, expressed in Sf9 cells with a baculovirus system and purified to homogeneity, was provided by H. Baylcy and S. Cheley (Worcester Foundation for Experimental Biology, Shrewsbury, MA).

Purification of Aplysia muscle $R$ subunit of PKA. M1 was isolated from frozen buccal muscle ( $800 \mathrm{gm}$ wet weight). Tissue was thawed at $4^{\circ} \mathrm{C}$ in $600 \mathrm{ml}$ of $10 \mathrm{~mm} \mathrm{~K}$ phosphate buffer $(\mathrm{pH} 6.8)$ containing 0.5 mM 2-mercaptoethanol, 2 mM EDTA, 2 mM EGTA, $10 \mathrm{~mm}$ benzamidine, $0.001 \%$ aprotinin, $1 \mathrm{~mm}$ phenylmethylsulfonylfluoride. All subsequent manipulations were at $4^{\circ} \mathrm{C}$. Purification on DEAE-52 cellulose (Whatman, Maidstone, England) was done as described by Beavo et al. (1974). Eluted fractions were assayed by immunoblotting using the antiN4 antibody. Fractions containing M1 were collected for further purification by affinity column chromatography with cAMP-agarose (Weber et al., 1979).

Purification of Aplysia $20 S$ proteasome. Proteasome was isolated from musclc. Although we cxpceted muscle to contain Iess proteasome (w/w) than nervous tissue (see Results), the relative abundance of muscle provides a convenient source for the structural studies described below. Muscle from the body wall and buccal mass was homogenized with a Kinematica Polytron, Model PT10-35 (Brinkman, Westbury, NY) in $50 \mathrm{~mm}$ Tris- $\mathrm{HCl}$ ( $\mathrm{pH} 7.2$ ) containing $5 \mathrm{~mm} \mathrm{MgCl}_{2}, 1 \mathrm{~mm}$ ATP, $1 \mathrm{~mm}$ dithiothreitol (DTT), $0.25 \mathrm{M}$ sucrose. The homogenate was subjected three times to $30 \mathrm{sec}$ high-speed bursts in a Waring blender and centrifuged for $1 \mathrm{hr}$ at $100,000 \times \mathrm{g}$. The resulting supernatant was centrifuged further for $5 \mathrm{hr}$ at $100,000 \times \mathrm{g}$. The resulting pellet was resuspended in $50 \mathrm{~mm}$ Tris- $\mathrm{HCl}(\mathrm{pH} 7.25)$ containing $50 \mathrm{~mm} \mathrm{KCl}, 5 \mathrm{~mm}$ $\mathrm{MgCl}_{2}, 0.5 \mathrm{~mm}$ ATP, $1 \mathrm{~mm}$ DTT, and $10 \%$ glycerol and applied to a Mono-Q column HR 10/10 (Pharmacia, Piscataway, NJ). The column was eluted with a linear gradient of $0-500 \mathrm{~mm} \mathrm{NaCl}$ in the buffer at a flow rate of $1 \mathrm{ml} / \mathrm{min}$. Peptidasc activity was assayed in each fraction using the artificial fluorogenic substrates, N-succinyl-leu-leu-val-tyr 7-amido-4-methylcoumarin (SUC-LLVY), N-t-boc-leu-arg-arg 7-amido-4-methylcoumarin (BOC-LRR), and N-CBZ-leu-leu-glu $\beta$-napthylamide (CBZ-LLE) from Sigma. After the fractions were combined and concentrated using Centriprep-10 and Centricon-10 concentrators (Amicon, Beverley, MA), they were applied to a Superose-6 HR 10/30 column (Pharmacia) equilibrated in the buffer containing $150 \mathrm{~mm} \mathrm{NaCl}$. The column was eluted with the same buffer at a flow rate of $0.25 \mathrm{ml} /$ $\min$. The collected fractions were assayed for peptidase activity and found to be highly enriched $(>95 \%)$ in proteasome subunits by Coomassie blue protein staining of SDS-polyacrylamide gels (Tanaka et al., 1988).

Electrophoresis and blotting of Aplysia 20 S proteasome. Two-dimensional electrophoresis (O'Farrell, 1975) was done on purified muscle proteasomes by Kendrick (Madison, WI). Molecular-weight standards were added to the agarose which sealed the tube gel to the slab gel. After SDS-PAGE (Laemmli, 1970), the proteins in the slab gel were transblotted onto Immobilon-P transfer membranes (Millipore, Bedford, MA) in $12.5 \mathrm{~mm}$ Tris- $\mathrm{HCl}$ ( $\mathrm{pH} 8.8$ ), $86 \mathrm{~mm}$ glycine, and $10 \%$ methanol overnight at $200 \mathrm{~mA}$. Blots were either stained and destained or treated for immunodetection as described below.

Amino acid sequence analysis. Sequence analysis of Immobilon-Pblotted proteins (Matsudaira, 1987) was done by the Columbia University Biopolymer Facility with an automated Applied Biosystems Sequence Analyzer, model 470A. Direct Edman degradation was possible only for two unblocked, endogenously generated proteolytic fragments ( $M_{r} 38,000$ and $M_{r}, 22,000$ ) of the muscle R subunit that was purified with intact M1 on CAMP-agarose. Since subunits of the proteasome are likely to be N-terminally blocked, sequencing of p28K, the Aplysia muscle proteasome subunit, was done on tryptic digests of the protein eluted from the Immobilon blot (Fernandez et al., 1992). Eluate in 0.1\% trifluroactetic acid (TFA) was injected onto a Vydac C18 $(0.21 \times 25$ $\mathrm{cm}$ ) column. Peptide fragments were separated by HPLC (Hewlett Packard 1090) at a flow-rate of $0.2 \mathrm{ml} / \mathrm{min}$ and monitored by absorption at $210 \mathrm{~nm}$. Buffer A contained 0.07\% TFA and Buffer B, 0.056\% TFA in acetonitrile. The gradient was run as follows: $2-30 \% \mathrm{~B}(0-63 \mathrm{~min}), 30$ $60 \%$ B (63-95 min), 60-80\% B (95-105 min).

cDNA synthesis and PCR amplification. RNA was prepared as described by Beushausen et al. (1988). cDNA was prepared from $2 \mu \mathrm{g}$ of total Aplysia nervous-tissue RNA primed with $2.5 \mathrm{~mm}$ random hexamers, and reverse transcribed using cloned Moloney murine leukemia virus reverse transcriptase (Perkin Elmer Cetus, Norwalk, CT) in the presence of $1 \mathrm{~mm}$ each of dATP, dTTP, dCTP, and dGTP. Oligonucleotides used as primers to amplify M1 cDNA transcripts were synthesized according to the cDNA sequence of N4 (Bergold et al., 1992). The sequences of sense oligonucleotides were (starting from the first nucleotide of the triplet encoding the $\mathrm{N}$-terminal methionine as number one: $1-21 ; 355-372 ; 490-510 ; 712-732 ; 949-969$; anti-sense oligonucleotides were: $340-360 ; 484-501 ; 865-885 ; 1114-1134$. The randomly primed cDNA was added to the $100-\mu 1$ reaction mixture containing 2 $\mathrm{mM} \mathrm{MgCl}, 50 \mathrm{~mm} \mathrm{KCl}, 10 \mathrm{~mm}$ Tris- $\mathrm{HCl}(\mathrm{pH} \mathrm{8.3)}$, $2.5 \mathrm{U}$ of AmpliTaq DNA Polymerase (Perkin Elmer Cetus), $0.4 \mathrm{~mm}$ of each primer (upstream and downstream) which was overlaid with $50 \mu$ l of mineral oil (Sigma). PCR amplification proceeded for 40 cycles with the following program: $94^{\circ} \mathrm{C}, 1 \mathrm{~min} ; 50^{\circ} \mathrm{C}, 2 \mathrm{~min} ; 72^{\circ} \mathrm{C}, 3 \mathrm{~min}$. The amplified products were electrophoresed in $4 \%$ NuSieve Agarose (FMC BioProducts, Rockland, ME) and detected with ethidium bromide.

Cloning and sequence analysis of PCR products. Fragments obtained by PCR amplification of muscle cDNA were ligated to the pCRII TA cloning plasmid (Invitrogen, San Diego, CA) and cloned into INVaF' $E$. coli (Invitrogen) as described by the supplier. Transformed colonies were incubated at $37^{\circ} \mathrm{C}$ overnight on kanamycin or ampicillin $(50 \mu \mathrm{g} /$ $\mathrm{ml}$ ) and $100 \mu \mathrm{l}$ of X-Gal $(40 \mathrm{mg} / \mathrm{ml})$ (Stratagene, La Jolla, CA). Since the TA vector is unstable, all white colonies were screened for inserts of new cDNA to distinguish between successful cDNA/vector ligations and blunt-end self-ligation resulting from loss of $3^{\prime} \mathrm{T}$ - overhangs from the vector, and grown overnight. Plasmids were then isolated by alkaline lysis using the small scale preparation of Sambrook et al. (1989). Clones containing the PCR fragments were identified by Eco-RI digestion and electrophoresis in $1.4 \%$ agarose. The cloned inserts were sequenced on both strands using SP6 and T7 sequencing primers on an Applied Biosystems DNA sequencer Model 373A by the Columbia University DNA Core Facility of the Cancer Center. Possible errors in amplification or sequencing were examined by additional reactions and cloning.

Radiolabeling. We photoaffinity labeled recombinant N4 and R subunits in homogenates of neuronal components and ARC muscle with ${ }^{32} \mathrm{P}-8-\mathrm{N}_{3}$-cAMP (ICN, Irvine, $\mathrm{CA} ; 60-70 \mathrm{Ci} / \mathrm{mmol} ; 1 \mathrm{Ci}=37 \mathrm{GBq}$ ) (Grcenberg ct al., 1987). Tissue homogenates were prepared in glassglass tissue grinders (Micrometric Instruments, Tampa, FL). Yeast cytochrome $\mathrm{c}$ (Cyt-c, Sigma) was iodinated by the chloramine-T method (Hunter and Greenwood, 1962) and bovine Ub (Sigma), as described by Ciechanover et al. (1980).

Protein degradation assays. Aplysia tissues were homogenized in 8 $\mathrm{mm} \mathrm{KCl}, 4 \mathrm{~mm} \mathrm{MgCl}, 0.5 \mathrm{~mm}$ DTT, $20 \mathrm{~mm}$ Tris- $\mathrm{HCl}$ (pH 7.6). The homogenate was centrifuged for $2 \mathrm{~min}$ at $3000 \times \mathrm{g}$. In some experiments proteasomes were removed by centrifugation for $6 \mathrm{hr}$ more at $100,000 \times g$ in the presence of $2 \mathrm{mM}$ ATP and $5 \mathrm{mM} \mathrm{MgCl}_{2}$ (Kanayama et al., 1992). Degradation was assayed by the disappearance of the radioactively labeled protein substrates using SDS-PAGE, autoradiography and scanning densitometry (Hoefer, San Francisco, CA). ${ }^{32} \mathrm{P} 8-\mathrm{N}_{3}-$ cAMP-labeled ARC M1 (5 $\mu \mathrm{g}$ of total protein; Bradford, 1976), recom- 
binant ${ }^{32} \mathrm{P}-8-\mathrm{N}_{3}-\mathrm{cAMP}-$ labeled $\mathrm{N} 4(20 \mathrm{ng})$ or $\mathrm{I}^{125}$-Cyt-c $(20 \mathrm{ng})$ were incubated in $100 \mu \mathrm{l}$ reaction volumes containing $5 \mathrm{~mm}$ DTT, $10 \mathrm{~mm}$ $\mathrm{MgCl}_{2}, 10 \mathrm{~mm} \mathrm{KCl}$, and $50 \mathrm{~mm}$ Tris- $\mathrm{HCl}(\mathrm{pH}$ 8). In some experiments, $0.5 \mathrm{~mm}$ ATP and an ATP regenerating system containing $10 \mathrm{~mm}$ creatine phosphate and $100 \mu \mathrm{g} / \mathrm{ml}$ creatine phosphokinase were added. Where indicated, the action of ATP was inhibited by omitting $\mathrm{MgCl}_{2}$ and adding $10 \mathrm{~mm}$ EDTA, or by adding $4 \mathrm{~mm}$ AMP-PCP [adenylyl ( $\beta$ $\gamma$-methylene)-diphosphonate] (Boehringer-Mannheim, Indianapolis, IN). At zero time and after $3 \mathrm{hr}$ at $15^{\circ} \mathrm{C}$, we added $50 \mu \mathrm{l}$ of $3 \times$ SDSPAGE (Laemmli, 1970) sample buffer (2\% SDS, 5\% 2-mercaptoethanol, $10 \%$ glycerol, $0.001 \%$ bromophenol blue, $62.5 \mathrm{~mm}$ Tris- $\mathrm{HCl}, \mathrm{pH}$ 6.8 ) and heated the samples for $3 \mathrm{~min}$ at $98^{\circ} \mathrm{C}$.

Ub-protein conjugation assay. Cyt-c $(540 \mu \mathrm{g})$ was added to $50 \mathrm{~mm}$ Tris- $\mathrm{HCl}$ ( $\mathrm{pH} 8.0$ ) containing $10 \mathrm{~mm} \mathrm{MgCl}, 1 \mathrm{~mm}$ DTT, 5 mM ATP, $10 \mathrm{~mm}$ creatine phosphate, $100 \mu \mathrm{g} / \mathrm{ml}$ creatine phosphokinase, $10 \mathrm{~mm}$ hemin, and $74 \mu \mathrm{g}$ Ub-depleted Aplysia tissues as described by Hershko et al. (1983) for the preparation of Fraction II from rabbit reticulocyte lysates. Conjugation was initiated by adding $2 \mu \mathrm{g}{ }^{125} \mathrm{I}-\mathrm{Ub}\left(5 \times 10^{6}\right.$ $\mathrm{cpm} / \mu \mathrm{g}$ ). The reaction was stopped after $1 \mathrm{hr}$ at $37^{\circ} \mathrm{C}$ with Laemmli sample buffer, and the samples subjected to SDS-PAGE.

Endopeptidase assays. Extracts $(10 \mu \mathrm{g})$ of nervous tissue or muscle were incubated at $25^{\circ} \mathrm{C}$ with the fluorogenic substrates SUC-LLVY or BOC-LRR $(100 \mu \mathrm{M})$ in $100 \mu \mathrm{l}$ of $50 \mathrm{~mm}$ Tris- $\mathrm{HCl}(\mathrm{pH} 7.3)$ containing $5 \mathrm{mM} \mathrm{MgCl}_{2}$ and $1 \mathrm{~mm}$ DTT. The reaction was stopped after $15 \mathrm{~min}$ with $1 \%$ SDS $(1 \mathrm{ml})$. Hydrolysis of the peptide was measured at 380 $\mathrm{nm}$ excitation and $440 \mathrm{~nm}$ emission.

Immunoblotting. Proteins extracted from nervous tissue and ARC muscle in $150 \mathrm{~mm} \mathrm{NaCl}, 3 \mathrm{~mm}$ EGTA, $0.5 \mathrm{~mm}$ 2-mercaptoethanol, 50 $\mathrm{mm}$ Tris- $\mathrm{HCl}(\mathrm{pH} \mathrm{7.6)}$ and separated on polyacrylamide SDS-PAGE, were transferred to nitrocellulose filters (Schleicher and Schuell, Keene, $\mathrm{NH}$ ) as described by Towbin et al. (1979). After the transfer, the filters were washed briefly with water. The Ub blots were placed for $30 \mathrm{~min}$ in boiling water because this treatment enhances detection by anti-Ub antibody (Wilkinson, 1990). Filters were washed with Tris-buffered saline [TBS; $10 \mathrm{~mm}$ Tris- $\mathrm{HCl}(\mathrm{pH} 7.4) 0.9 \% \mathrm{NaCl}$ ] and incubated for 2 $\mathrm{hr}$ with 5\% BSA in TBS. The filters were then treated for $3 \mathrm{hr}$ with 1:1000 dilution of primary antibody in TBS, $0.1 \%$ Tween 20 and washed five times (10 min each) with TBS containing $0.2 \%$ NP 40 (Integrated Separation Systems, Natick, MA). After they were washed three times for $10 \mathrm{~min}$ with TBS, the blots were treated for $30 \mathrm{~min}$ with alkaline phosphatase-conjugated anti-rabbit antibody (1:5000 dilution made in TBS, $0.1 \%$ Tween 20 ). After 5-10 min washes with TBS containing $0.2 \%$ NP 40 , immune complexes were stained with nitro blue tetrazolium and 5-bromo-4-chloro-3-indolyl phosphate (Promega). In some experiments, immune complexes were visualized by enhanced chemiluminescence (Amersham, Arlington Heights, IL). The blots were treated as described above except that they were blocked with $10 \%$ nonfat dry milk and the secondary antibody used was anti-mouse peroxidase-linked IgG (Amersham) at 1;2000 dilution.

Statistics. All experiments were done at least three times. Where appropriate, results are presented as means \pm SEM. Significant differences were assessed using Student's $t$ test.

\section{Results}

\section{Regional distribution of the Ub system in neuron:}

We analyzed components of the Ub system in synaptosomes and neuronal regions separated by dissection. The Ub system is present throughout the neuron. Immunoblotting shows the presence of both free $\mathrm{Ub}$ and high molecular-weight Ub-conjugates (Fig. $1 A$ ) in synaptosomes, cell bodies, neuropil, and in extruded axoplasm. The cell bodies and axoplasm contain specific Ub-conjugates not detected in other regions (Fig. 1Aii). Proteasomes (Fig. $1 B$ ) are also found in all of the regions examined.

\section{Similarity of tissue-specific $R$ isoforms}

M1 might be resistant to degradation in muscle because of some structural feature. Its mobility on reducing SDS-PAGE is retarded compared to N4, corresponding to an apparent difference of $M_{r} \sim 2000$. For this reason we compared these tissue-specific isoforms and found that the amino acid sequences of M1 and $\mathrm{N} 4$ are identical. The apparent difference in size is most likely

\section{A Ubiquitin}

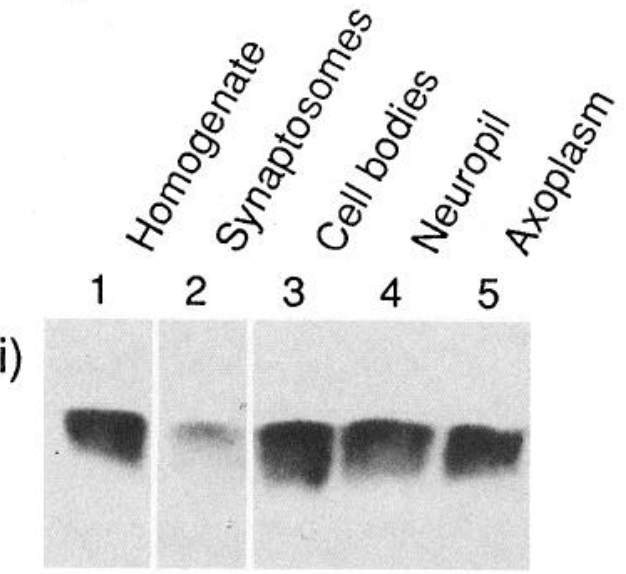

ii)

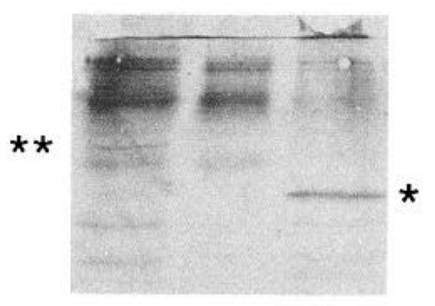

\section{B Proteasome (p27)}

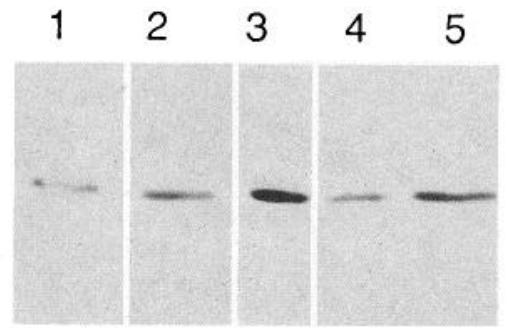

\section{Synaptotagmin}

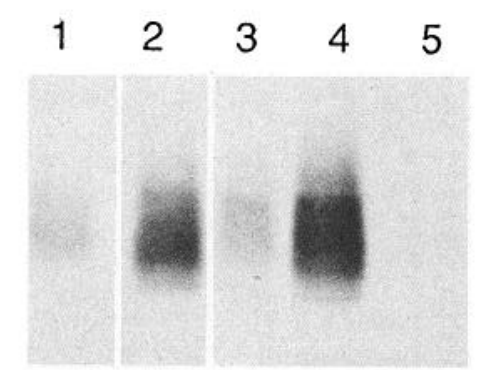

Figure 1. Regional distribution of components of the $\mathrm{Ub}$ system. The amount of free $\mathrm{Ub}(A i)$, conjugated $\mathrm{Ub}(A i i)$, and $\mathrm{p} 27 \mathrm{~K}$ proteasome subunit $(B)$ were assessed in different subcellular fractions (10 $\mu \mathrm{g}$ protein) by immunoblotting after SDS-PAGE with $15 \%(A)$ or $12 \%(B)$ polyacrylamide using the appropriate antibodies (see Materials and Methods). Homogenates (lanes 1), were fractionated on a two-step sucrose gradient which has previously been shown by electron microscopy (Chin et al., 1989) to yield synaptosomes (lanes 2). Cell bodies (lane 3), neuropil (lane 4), and axoplasm (lane 5) were obtained by dissection. Synaptotagmin immunoreactivity $(C)$ was used to show the abundance of nerve endings in the fractions. Specific high-molecular weight Ub-conjugates in cell bodies (Aii, lane 3) and axoplasm (Aii, lane 5) are indicated by asterisks. 


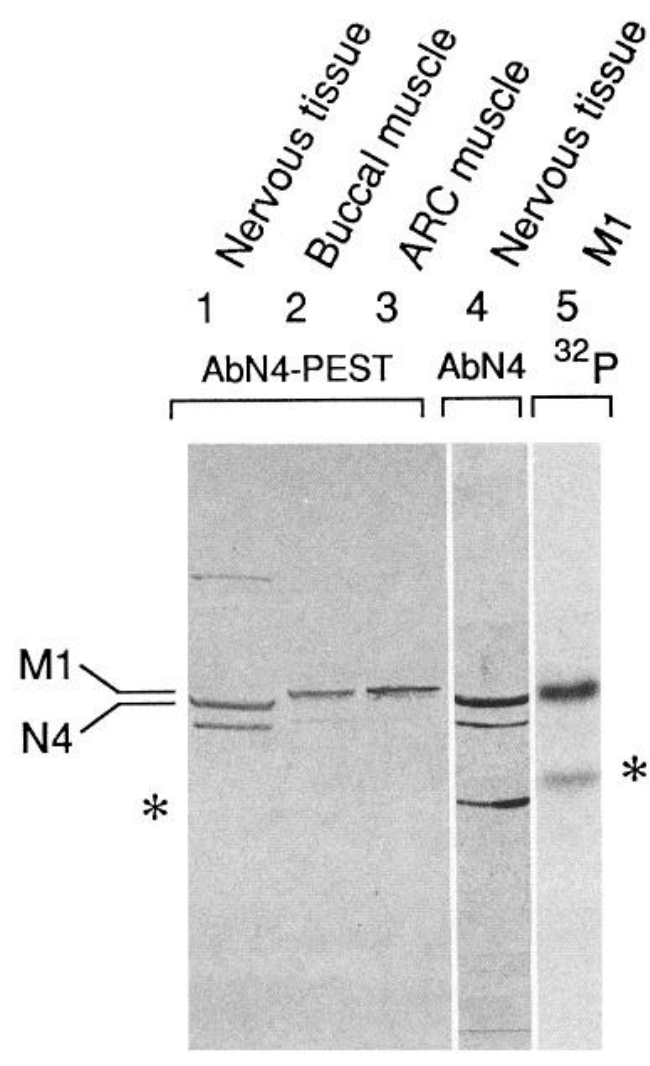

Figure 2. Immunoblot analysis of $\mathrm{R}$ subunits in Aplysia tissues. AbN4-PEST, an antibody raised against the unique N-terminal PEST region of $\mathrm{N} 4$, was used to immunoblot nervous tissue extract (lane 1), buccal muscle (lane 2), and ARC muscle (lane 3). AbN4, an antibody raised against intact recombinant N4, was used to immunoblot nervous tissue extract (lane 4). DEAE-purified M1 $(10 \mu \mathrm{g})$ was photoaffinity labeled with ${ }^{32} \mathrm{P}-8 \mathrm{~N}_{3}$-cAMP and subjected to SDS-PAGE followed by autoradiography (lane 5). Asterisk, Position of the proteolytic fragment generated by cleavage at the hinge region of the $\mathrm{R}$ subunits. The high molecular-weight band in lane 1 is the N1 R isoform (Palazzolo et al., 1989).

the result of a posttranslational modification that retards M1's electrophoretic mobility. This idea is based on structural evidence obtained by immunoblotting with $\mathrm{R}$ subunit antibodies against a unique $\mathrm{N}$-terminal sequence, cDNA cloning of M1, and $5^{\prime}$ extension analysis.

Immunoblotting. A polyclonal antibody (AbN4-PEST) was raised against a synthetic icositripeptide corresponding to a sequence $\left(\mathrm{Glu}^{63}-\mathrm{Gln}^{85}\right)$ within the unique region near the N-terminus of N4. This portion of the molecule is enriched in proline, glutamate, serine, and threonine (PEST) but has no sequence similarity to the variable PEST regions in $\mathrm{R}$ subunits of other animals (Bergold et al., 1992). As shown by immunoblotting, AbN4-PEST recognizes the N4 isoform and two other structurally related neuronal Aplysia R subunits separated by one-dimensional SDS-PAGE (Fig. 2, lane 1) (Palazzolo et al., 1989). The antibody also recognizes intact M1 in extracts of whole buccal mass and of ARC muscle (Fig. 2, lanes 2 and 3). It does not, however, recognize Aplysia $\mathrm{N} 2$ and vertebrate $\mathrm{R}_{\mathrm{I}}$ (not shown). The C-terminal cAMP-binding fragment generated by proteolysis of $\mathrm{N} 4$ at the hinge region (asterisk) serves as an internal negative control, since it does not contain the PEST region. [Cleavage at the protease-sensitive hinge region (Taylor et al., 1990) occurs during the extraction of $\mathrm{R}$, both in verte- brates and invertebrates.] In contrast, as described by Bergold et al. (1992), a polyclonal antibody raised against recombinant N4 recognizes the cAMP-binding fragment (Fig. 2, lane 4, asterisk). The identity of the immunostained band from muscle was confirmed by photoaffinity-labeling with ${ }^{32} \mathrm{P}-8 \mathrm{~N}_{3}$-cAMP (Fig. 2, lane 5). The apparent differences in size of the proteolytic fragments suggest that the small electrophoretic difference observed between the mobilities of the intact $\mathrm{R}$ isoforms is located in the C-terminus (cAMP-binding portion) of the subunit.

Cloning M1. We obtained the cDNA sequence of M1 (Fig. 3) by PCR amplification and cloning: several paired oligonucleotide primers, composed of overlapping sequences that are identical to the cDNA encoding N4 (Bergold et al., 1992) were used to amplify cDNA fragments from muscle mRNA. Insertion of each PCR product into a pCRII TA-cloning plasmid vector enabled us to sequence the complete coding region of M1 cDNA. The sequence of M1 is identical to that of N4, suggesting that the two isoforms are encoded by the same gene. M1 does not contain additional coding sequences at its $3^{\prime}$-end (Fig. $3 B$ ) or at its $5^{\prime}$-end as revealed by primer extension analysis (not shown). This analysis was performed using a primer consisting of the variable oligonucleotide sequence 1 to $50,3^{\prime}$ to $5^{\prime}$. We found that the sites of transcription are identical in N4 and M1. We also sequenced two proteolytic fragments of M1 (Fig. 3). These are identical to N4.

Susceptibility of tissue-specific $R$ isoforms to degradation. We compared the degradation of ${ }^{32} \mathrm{P}-8 \mathrm{~N}_{3}$-cAMP-labeled $\mathrm{N} 4$ and M1 in tissue extracts, and found that M1 is readily degraded in nervous tissue (Fig. $4 A$ ) but is much more stable in muscle (Figs. $4 B, 5$, lane 1). Similarly N4, which is degraded in nervous tissue (Hegde et al., 1993), is stable in muscle (Fig. 4C). Degradation of ${ }^{125} \mathrm{I}-\mathrm{Cyt}-\mathrm{c}$ was assayed as a test substrate for the Ub system under conditions similar to those used for R subunits. Because it does not require additional targeting factors (Pickart and Rose, 1985; Sokolik and Cohen, 1991), these assays should reflect the basal activity of the Ub pathway. As shown in Figure 5, both M1 and Cyt-c are readily degraded in extracts of nervous tissue by a process that is dependent on ATP, Ub and proteasomes: $75 \%$ of $\mathrm{M} 1$ is degraded in $3 \mathrm{hr}$ in the presence of $\mathrm{Mg}^{2+}$-ATP but is significantly $(P<0.05)$ inhibited by EDTA, by the nonhydrolyzable ATP-analog, AMP-PCP, and by the competitive inhibitor, methylated Ub. Furthermore, removal of proteasomes by ultracentrifugation significantly $(P<0.05)$ blocks degradation (Fig. 5), and addition of the sedimented pellet back to the supernatant restores this activity. These observations, together with our earlier results on degradation of N4 (Hegde et al., 1993), indicate that $\mathrm{M} 1$ and $\mathrm{N} 4$ are susceptible to degradation by the Ub pathway in nervous tissue extracts. In contrast, not more than $10 \%$ of M1, N4, or Cyt-c are degraded in extracts of muscle.

Thus, structural differences between isoforms do not seem to explain the greater susceptibility of $\mathrm{R}$ subunits to degradation in neurons relative to muscle. We therefore looked for possible tissue-specific specializations of the Ub system. Tissue-specific differences could affect two complex steps of the pathway: conjugation of $\mathrm{Ub}$ to the protein substrate or degradation of the ubiquitinated protein (most recently reviewed by Ciechanover and Schwartz, 1994). (These possibilities are not mutually exclusive.) Which of these two parts of the Ub pathway might limit degradation of $\mathrm{R}$ subunits? The differences that we observed in the capacity of muscle and nervous tissue extracts to degrade protein substrates gives us the possibility to answer this question. 
A

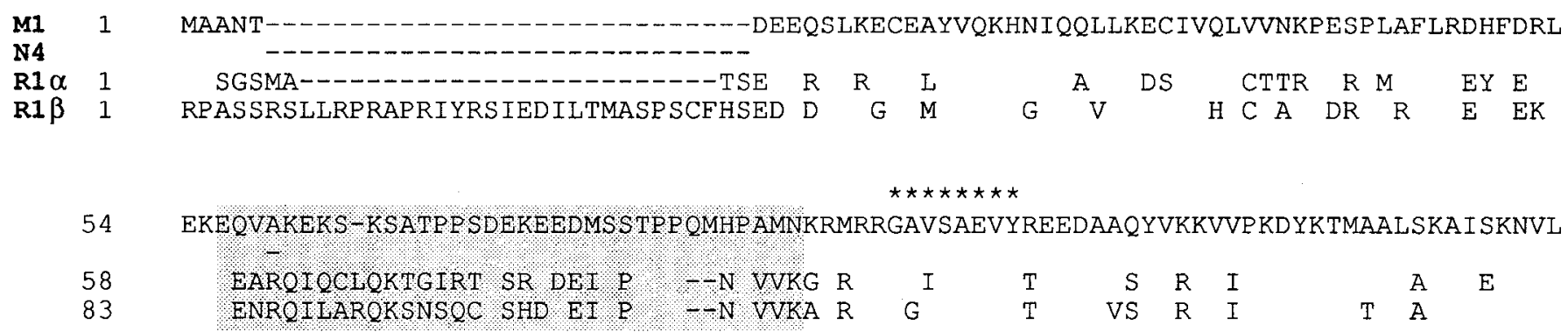
DVKLWGIDRDSYRR I LMGST IRKRK IYEDF LSKVS I LENLDKWERL TVADALEPVQFEDKEE IVRQGEPGEDFF I I LEGSAA

$\mathrm{N}$

L

L $\quad M \quad E$

$S$

$S E$

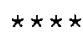

GQK V

G K V

\section{B}

M1 372

$\begin{array}{ccccccccc}S & F & V & S & L & S & V & & \\ \text { AGC } & \text { TTT } & \text { GTA } & \text { TCC } & \text { CTG } & \text { TCG } & \text { GTG } & \text { TAG } & \text { GGG } \\ \text { ACC } & \text { CC }\end{array}$

Figure 3. Structure of R subunits. A, Amino acid sequence. The inferred sequence of M1 is aligned with N4 (Bergold et al., 1992), murine $\mathrm{R}_{\mathrm{I}} \alpha$ and $\mathrm{R}_{\mathrm{t}} \beta$ (Clegg et al., 1988). Only residues differing from M1 are shown. Sequences obtained by Edman degradation are marked by asterisks. Shaded area spans the PEST region (residues 56-89). Solid circles indicate the position of $\mathbf{W}(259)$ and $\mathbf{Y}(370)$ that bind ${ }^{32} \mathrm{P} 8 \mathrm{~N}_{3}$-cAMP. $B$, Sequence of $3^{\prime}$ region. Sequences of M1 and N4 before and after the stop codon (TAG).

Proteasome in muscle and nervous tissue. The $26 \mathrm{~S}$ proteasome is a dumb-bell shaped particle that consists of two domains: a cylindrical core $(20 S)$ with terminal cap-like regions (for recent reviews, see Rechsteiner et al., 1993; Goldberg, 1995). Endopeptidase activity resides in the core domain and is similar in all eukaryotic cells examined (Orlowski, 1990; Goldberg, 1992), while the two terminal domains are thought to be regulatory and vary among tissues (Dahlmann et al., 1991; Ikai et al., 1991; Gray et al., 1994). We therefore characterized Aplysia core subunits in order to assess the total amount of $26 \mathrm{~S}$ proteasome in the two tissues.

Subunit composition and immunodetection. To detect major subunits of the catalytic $20 \mathrm{~S}$ core, we first isolated the $20 \mathrm{~S}$ proteasome from Aplysia muscle and analyzed its subunit composition by two-dimensional electrophoresis (Fig. 6A). As expected from characterization of proteasomes in other organisms, the $20 \mathrm{~S}$ Aplysia proteasome was resolved into about 20 different proteins, some of which differ only by posttranslational modifications (see for example Haass and Kloetzel, 1989; Yoshimura et al., 1993). Immunoblotting of the two-dimensional gel with MAb 7A11 (Fig. $6 B$ ) shows that this anti-human proteasome antibody recognizes a major component $\left(M_{r} 27,000\right)$ of the Aplysia $20 \mathrm{~S}$ proteasome, which appears to be made up of several electrophoretic variants that differ only by charge. We next raised a polyclonal anti-peptide antibody to $\mathrm{p} 28 \mathrm{~K}$, a second major subunit of Aplysia proteasome (Fig. 6A). Three tryptic peptides from this subunit (see Materials and Methods)_LYQAEYAF, XXPAGYYXGFK, and LEANSFLEK - correspond closely to amino acid sequences in the C9 subunit of the human 20S proteasome (Bey et al., 1993). LEANSFLEK was used to raise an anti-peptide antibody (Ab 9410).

Amounts of proteasome and ubiquitin in nervous tissue and muscle extracts. The activity of the proteasome may be limiting in muscle. Immunoblot analyses of muscle and nervous tissue using the two antibodies, MAb 7A11 (Fig. 7A, top) and Ab9410 (Fig. 7A, bottom), indicate that the amount of proteasome is about sixfold greater in nervous tissue than in muscle. In addition, we measured chymotrypsin- and trypsin-like endopeptidase activities in tissue extracts. Both activities are three to four times greater in nervous tissue than in muscle (Fig. 7B). By immunoblot analysis and densitometry, we found that the concentration of unconjugated $\mathrm{Ub}(1 \mu \mathrm{M})$ in SDS-extracted 


\section{A}

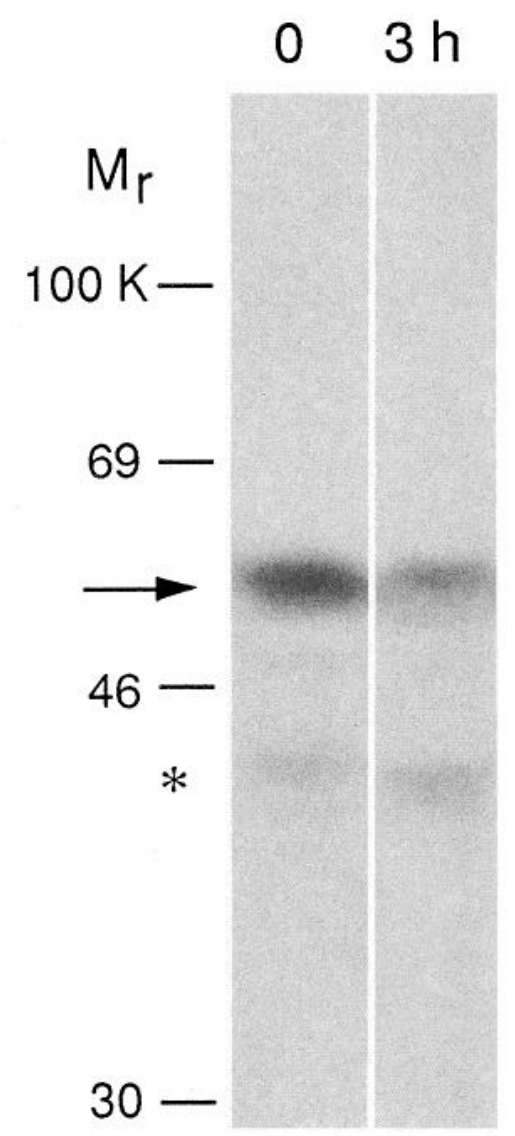

$\mathrm{B}$

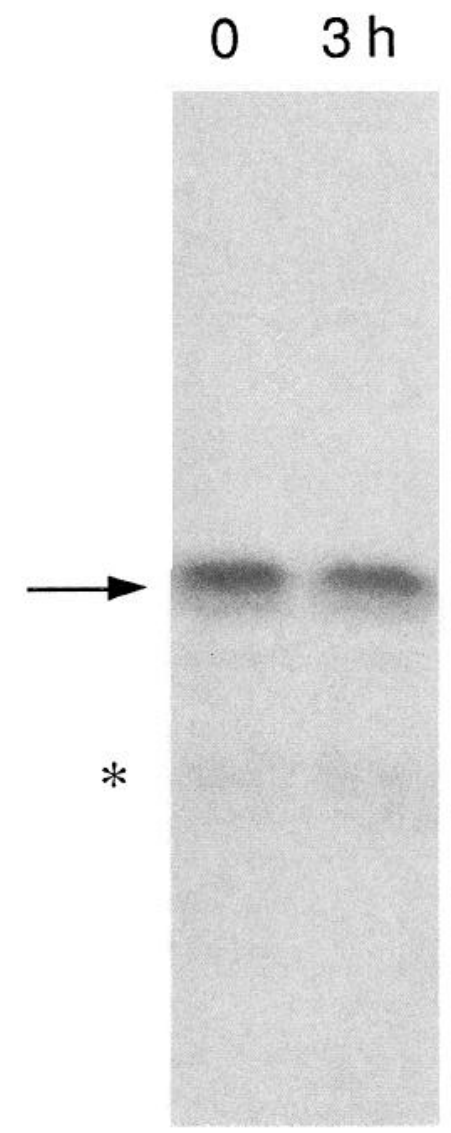

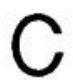

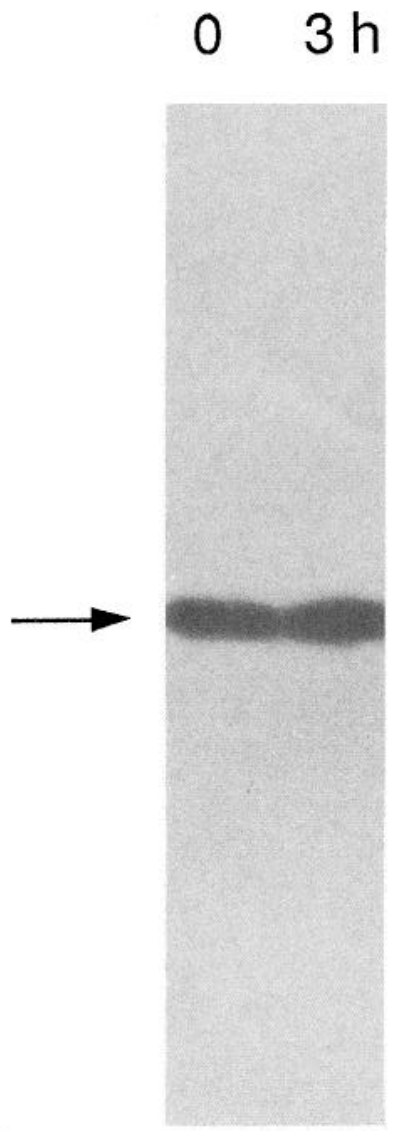

Figure 4. Degradation of R subunits in extracts of nervous tissue and ARC muscle. Degradation of ${ }^{32} \mathrm{P}$-photoaffinity-labeled M1 was assayed in extracts of nervous tissue $(A)$ and muscle $(B)$. Degradation of ${ }^{32} \mathrm{P}$-labeled N4 was assayed in extracts of muscle $(C)$ as described for nervous tissue by Hegde et al. (1993). After the $3 \mathrm{hr}$ incubation, samples were separated by SDS-PAGE and the gels autoradiographed. Arrow, M1 in $A$ and $B$ and N4 in C; asterisk, fragment generated by proteolysis at the hinge region. Molecular weight markers $\left(\times 10^{-3}\right)$ are indicated at left.

whole homogenates of muscle is $5 \%( \pm 0.9 \%, n=6)$ of that in nervous tissue (Fig. 7C). The total amounts of high molecularweight, immunoreactive Ub-conjugates, however, are similar. Comparable amounts of stable Ub-conjugates, despite large differences in free Ub, suggest that the two tissues differ in their ability to recycle $\mathrm{Ub}$. Consistent with this idea, we found that the ability of nervous tissue and muscle extracts to catalyze the formation of Ub-conjugates appears to be similar (data not shown). Since it is difficult to quantify amounts of multiple high molecular-weight conjugates, Cyt-c was used as the substrate in these experiments because it forms mainly mono- and di-ubiquitinated stable intermediates (Sokolik and Cohen, 1991).

\section{Reconstitution of the Ub system in muscle extract}

The inability of muscle to degrade $\mathrm{R}$ subunits may result from limiting component(s) of the Ub system. Since the amount of $\mathrm{Ub}$ is much greater in nervous tissue, we first assayed the degradation of M1 or Cyt-c, adding $20 \mu \mathrm{M} \mathrm{Ub}$ to muscle extract in order to match the amount of unconjugated $\mathrm{Ub}$ normally present in extracts of nervous tissue (Fig. 8). Adding extra Ub failed to increase the degradation of either substrate, suggesting that free $\mathrm{Ub}$ is not limiting in muscle. Similar experiments were then performed, now adding back a proteasome-enriched fraction obtained by differential ultracentrifugation of muscle extract (see
Materials and Methods). In the presence of a threefold excess of muscle proteasome, M1 and Cyt-c are significantly $(P<0.05)$ degraded to the same extent as in nervous tissue extracts, while degradation is blocked by EDTA. It was still important to show that this degradation is Ub-dependent, since the proteasome can, in rare instances, degrade nonubiquitinated protein substrates (Murakami et al., 1992). The Ub requirement for the degradation of M1 and Cyt-c is shown by competitive inhibition with methylated Ub. Degradation in reconstituted muscle extract is independent of the source of proteasome, since we obtained similar results with added proteasome from nervous tissue (Fig. 8).

\section{Discussion}

\section{The Ub system is present in nerve terminals}

We show that the Ub system is present in nerve terminals and might operate to produce the persistent PKA activity observed in presynaptic facilitation. Immunoblot analyses of Ub and proteasomes indicate that these components can enter the axon and reach nerve endings. We find regional differences in stable, highmolecular weight Ub-conjugates. Some conjugates are seen only in cell bodies and others only in axons. These observations bolster earlier indications that the Ub system also functions in axons (Bizzi et al., 1991; Savedia and Kiernan, 1994). It has already been shown that synaptic proteins are ubiquitinated in vertebrate 


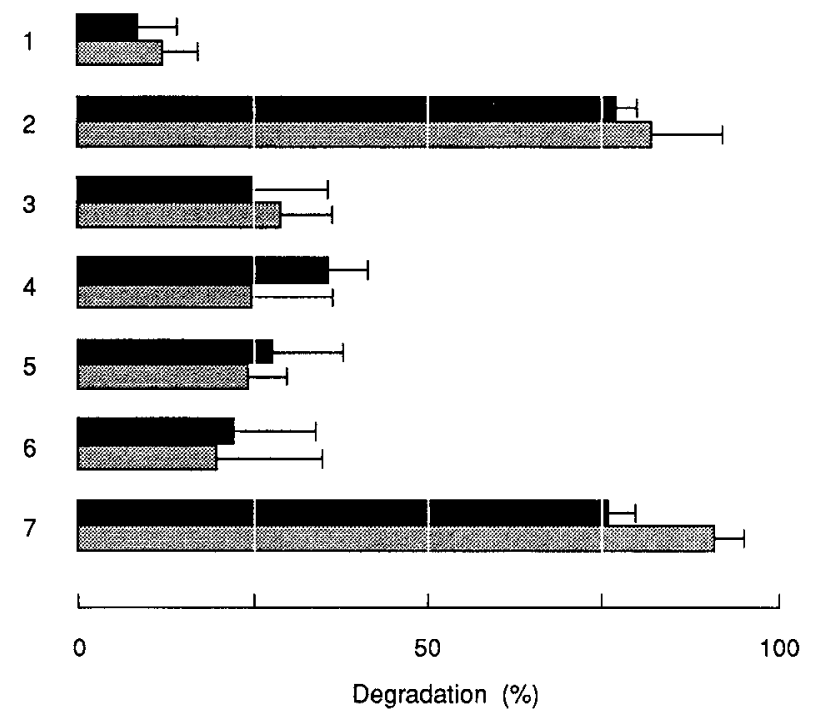

Figure 5. Degradation of $\mathrm{MI}$ and Cyt-c in extracts of ARC muscle and nervous tissue. ${ }^{32} \mathrm{P}-8 \mathrm{~N}_{3}$-cAMP-labeled M1 (solid bars) or ${ }^{125} \mathrm{I}-\mathrm{Cyt}-\mathrm{c}$ (stippled bars) were incubated in the complete reaction mixture for 3 $\mathrm{hr}$ (see Materials and Methods) containing extracts of muscle $(1)$ or nervous tissue (2-7); 2, complete nervous tissue reaction mixture; 3 , in the presence of EDTA; 4, with AMP-PCP; 5, with methylated Ub; 6 , in proteasome-depleted nervous tissue extracts; and 7, in a reconstituted system obtained by adding back the resuspended pellet (Hegde et al., 1993).

nervous tissue (Chapman et al,, 1994). Our results using antiproteasome antibody MAb 7All provide evidence that ubiquitinated proteins also can be degraded in nerve terminals. The idea that proteasomes might function directly at the synapse is supported by experiments that implicate proteasomes in regulating neurite outgrowth (Tsubuki et al., 1993).

\section{N4 and MI do not differ critically in structure}

In vertebrates, muscle-specific $\left(R_{I} \alpha\right)$ and neuronal $\left(R_{I} \beta\right)$ isoforms differ slightly (McKnight et al., 1988; Clegg et al., 1988), particularly in the N-terminal portion of the molecule (see Fig. 3). A difference in amino acid sequence between N4 and M1 might have explained M1's stability in muscle. Of special interest were possible differences in PEST regions, since these regions have been postulated to target proteins for degradation (Rogers et al., 1986).

Several lines of evidence suggest that N4 and M1 may be encoded by the same transcript. First, the sequence of MI inferred from cDNA cloning is identical to that of N4. While the PCR cloning procedure used might have amplified a minor transcript, $5^{\prime}$ primer extension analysis, which does not depend upon amplification indicates that the sites of transcription in M1 and $\mathrm{N} 4$ are identical. Further, M1 reacts not only with an antibody specific for the unique N4 PEST sequence, but also with an antibody against recombinant N4 (Bergold et al., 1992). The small apparent difference in size between the two isoforms might be explained by an as yet unidentified posttranslational modification within the C-terminal portion of M1. Although this part of the molecule contains the two cAMP-binding domains (Taylor et al., 1990; Bergold et al., 1992), we have not yet detected any functional significance of this modification. Final proof of the identity of $\mathrm{M} 1$ and $\mathrm{N} 4$ requires complete amino acid sequencing.

\section{Proteasomes in nervous tissue and muscle differ in their capacity to degrade $R$ subunits}

Immunoblot analyses indicate that the amount of proteasomes is greater in nervous tissue than in muscle. We also find endopeptidase activity in extracts to be greater in nervous tissue. These analyses suggest that the capacity of the proteasome can be limiting. But we also find a large difference in amounts of free $\mathrm{Ub}$, which is 20-fold greater in nervous tissue than in muscle. A low amount of free Ub could be limiting in muscle. Alternatively, it could reflect a physiologically significant difference between the tissues to recycle $\mathrm{Ub}$, thereby affecting proteasome activity (Hadari et al., 1992). In support of this second idea, we find that the Ub-immunoblots appear not to differ in the total amount of high molecular-weight conjugates. We also could not detect differences in the ability of these tissues to conjugate Ub to Cytc. Recycling of Ub is carried out by Ub carboxyl-terminal hydrolases, a heterogeneous family of enzymes that is only partly characterized (Hershko and Ciechanover, 1992). Some of these hydrolases cleave peptide bonds to release Ub monomers from polyUb precursors. Others cleave the isopeptide bonds formed between activated $\mathrm{Ub}$ and lysine residues on polypeptide substrates or between $\mathrm{Ub}$ monomers in multiUb chains extending from the lysine residues during substrate degradation by the proteasome.

By reconstituting the $\mathrm{Ub}$ system in extracts of muscle, we present evidence indicating that degradation by the proteasome, rather than $\mathrm{Ub}$ conjugation, is the step limiting the basal activity of the pathway. While the addition of a large cxcess of Ub has no effect on Ml's degradation, increasing the concentration of proteasomes is sufficient to degrade M1, N4 and Cyt-c in extracts of muscle to the extent observed in extracts of nervous tissue. This approach of mixing two types of cell-free tissue extracts is pragmatic, with the aim of identifying regulatory factors in an animal for which mutational analysis has not yet been possible. A similar approach, mixing different kinds of clam oocyte extracts, was used by Hershko et al. (1994) to identify specific components responsible for ubiquitination of cyclin.

\section{The proteasome may be a site for regulating the persistent activation of $P K A$ in sensory neurons}

The amount of the fraction that was obtained by differential centrifugation and added to muscle extracts to degrade $\mathrm{R}$ subunits brings the concentration of proteasome to that estimated in neurons, suggesting that the lower capacity of the proteasome explains the inability of muscle to degrade $R$. The increased capacity of nervous tissue could result from greater amounts of proteasomes alone or from proteasomes and their modulatory factors that sediment with the $100,000 \times g 6 \mathrm{hr}$ pellet. How can this idea be reconciled with the general belief that Ub-mediated degradation is regulated at the level of Ub conjugation (Finley and Chau, 1991) and what can be inferred about how degradation of the $\mathrm{R}$ subunit isoforms is regulated in sensory neurons?

Factors that modulate proteasome activity could regulate the neuron's ability to respond to sensitizing stimuli. This idea is in accord with the observation that proteasomes are induced in vertebrate skeletal muscle during fasting and denervation atrophy (Medina et al., 1992; Mitch et al., 1994). In addition, two MHCencoded subunits which substitute for constitutive counterparts are upregulated by $\gamma$-interferon in lymphocytes (Goldberg and Rock, 1992; Gaczynkska et al., 1993). Moreover, degradation of protein substrates is regulated by inhibitory (Li et al., 1991; Chu- 
A

\section{$\mathrm{Mr}_{\mathbf{r}}$}

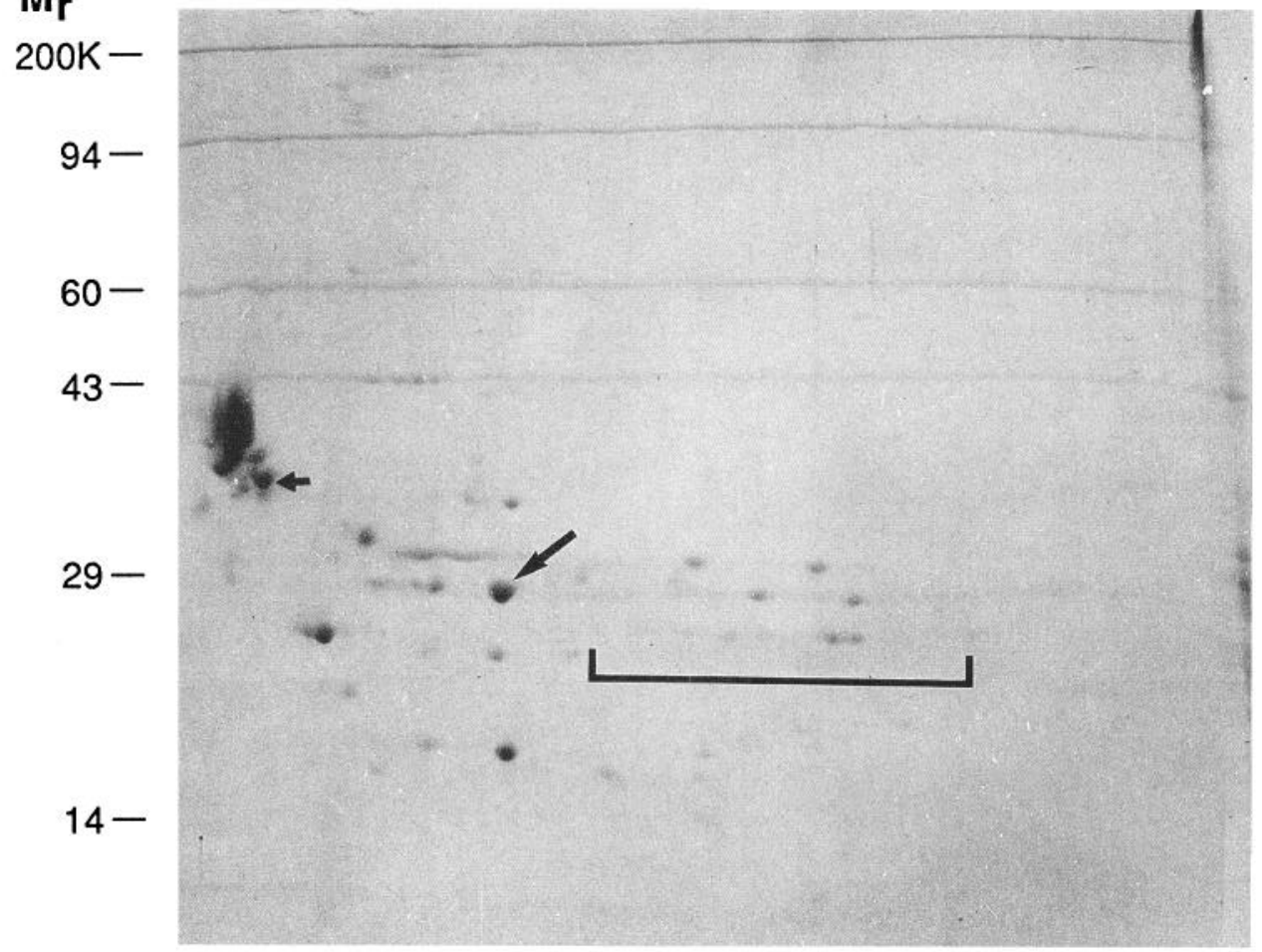

B

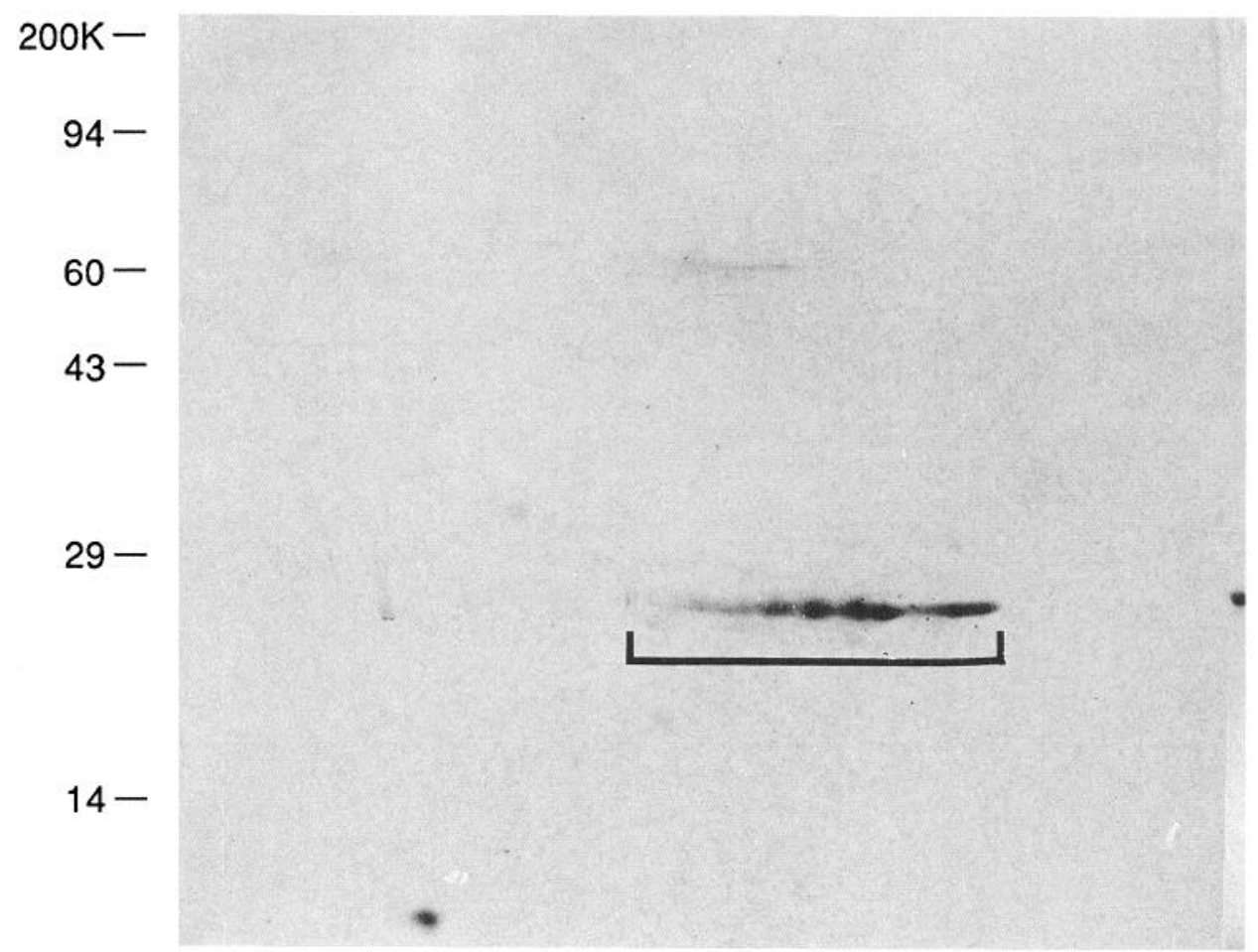

Figure 6. Two-dimensional electrophoresis of Aplysia 20S proteasome. Proteasomes were isolated from muscle, subjected to two-dimensional electrophoresis and electroblotted. A, Coomassie-blue staining shows the subunit composition of the proteasome. p28K is marked by a slanted arrow. Electrophoretic variants of $\mathrm{p} 27 \mathrm{~K}$ recognized by $\mathrm{MAb} 7 \mathrm{~A} 11$ are indicated by a square bracket. Thin lines across the blot are molecular-weight standards, indicated on the left. Tropomyosin added as internal standard is seen as two spots of similar pI; the lower one $\left(M_{r} 33,000 ;\right.$ pI 5.2$)$ is marked by a short arrow. $B$, Immunoblot with MAb 7A11.
Ping et al., 1992; Driscoll et al., 1992) and activator (DeMartino et al., 1994) subunits in the terminal cap regions of proteasomes. Proteasomes have been shown to be substrates for protein kinases including PKA (Pereira and Wilk, 1990) and casein kinase
II (Ludeman et al., 1993), both of which appear to remain associated with proteasomes during isolation. [Protein kinases that are associated with microtubules (Cheley et al., 1994) or membrane-bound protein phosphatases (Endo et al., 1992) in Aplysia 
A

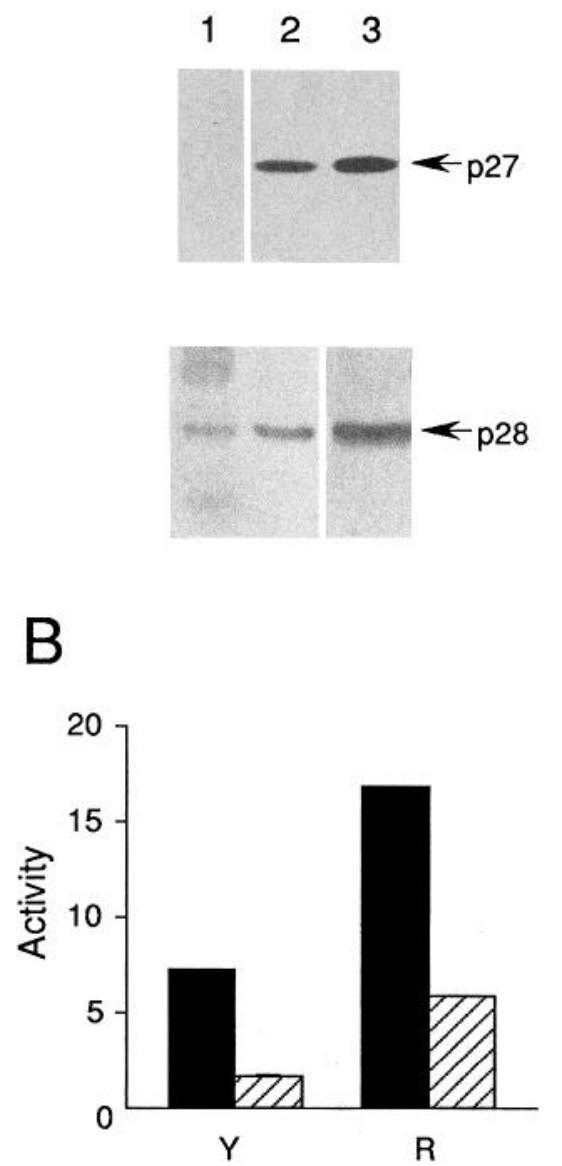

C

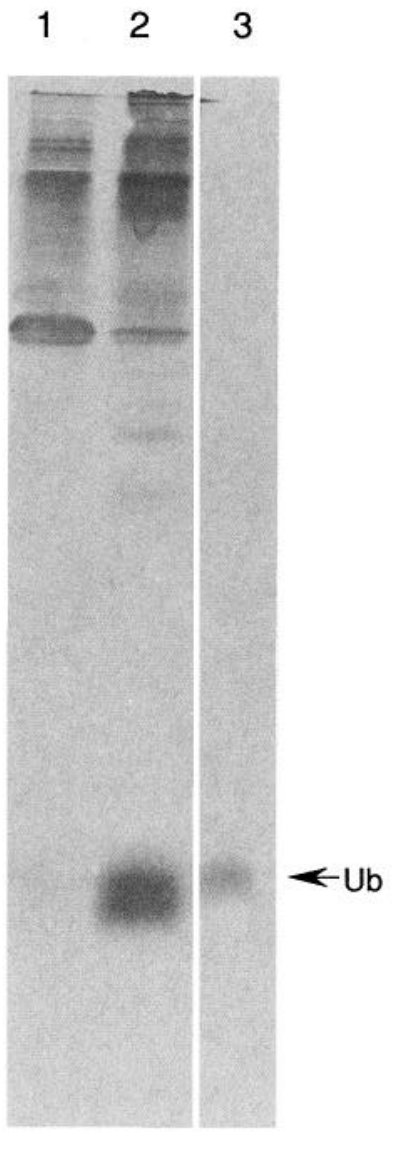

Figure 7. Proteasome and $\mathrm{Ub}$ in nervous tissue and ARC muscle. A, MAb 7A11 that detects p27K (top gel) and Ab-9410 that detects p28K (bottom gel) were used to immunoblot the $5 \mathrm{hr} 100,000 \times \mathrm{g}$ proteasome pellet from muscle (lanes 1 ), nervous tissue (lanes 2 ) each with $20 \mu \mathrm{g}$ total protein and $1 \mu \mathrm{g}$ purified Aplysia $20 \mathrm{~S}$ proteasome (lanes 3). We could detect p $27 \mathrm{~K}$ in muscle only after prolonged development of the blot (not shown). As measured by densitometry, the amounts of p27K and p28K in muscle were $13 \%$ and $18 \%(n=6, P<0.05)$ of those in nervous tissue. To avoid loss of proteasome by adherence to myofibrils, the crude proteasome fraction was prepared after homogenization of the muscle without any low speed initial centrifugation. Proteins were separated on a $12 \%$ polyacrylamide gel. $B$, Resuspended $100,000 \times g$ proteasome pellets from nervous tissue (solid bars) and muscle (stippled bars) were assayed for chymotryptin-like endopeptidase activity using SUC LLVY ( $Y$ ) and tryptin-like endopeptidase activity using BOC-LRR $(R)$ as described in Materials and Methods. Activity, A unit is 1 nmol substrate hydrolyzed per milligram of protein per hour at saturating substrate concentrations. Differences in both activities are statistically significant $(P<0.01$ for $Y$ and $P<0.03$ for $R$ ). A third type of endopeptidase activity characteristic of the proteasome, cleaving bonds on the carboxyl-side of acidic residues, is too low in unfractionated tissue extracts to provide reliable data, although we have been able to measure this activity in purified muscle proteasomes of Aplysia. C, A polyclonal antibody against Ub was used to immunoblot homogenates (10 $\mu \mathrm{g}$ of total protein) of muscle (lane 1 ), nervous tissue (lane 2) and $10 \mathrm{ng}$ of bovine Ub (lane 3) after SDS-PAGE in 15\% polyacrylamide. We could detect free Ub in muscle by prolonged alkaline phosphatase reaction. The amount of free Ub in muscle is $5 \pm 0.9 \%(P<0.05)$, that of nervous tissue as estimated by densitometry. Since the muscle extract might contain peptidases that cleave the immunoreactive ubiquitin C-terminal di-peptide, we did control experiments spiking the muscle extract with different amounts of bovine ubiquitin, and found no evidence for degradation (data not shown). To ensure that Ub was not lost by adherence to myofibrils or other cytoskeletal elements, whole homogenates were extracted directly with $2 \%$ SDS.

neurons, however, are probably eliminated from our reconstitution experiments during the first-step of differential centrifugation after $1 \mathrm{hr}$ at $100,000 \times \mathrm{g}$.) Still further, Hadari et al. (1992) postulated that the disassembly and dissociation of ubiquitinated-protein remnants limits the activity of $26 \mathrm{~S}$ proteasomes and that turnover of these Ub-conjugates is enhanced by a Ub C-terminal hydrolase that is associated with the proteasome. Hegde et al. (1994) suggested that proteasomes in Aplysia neurons might be regulated through the induction of a neuronal Ub carboxyl-terminal hydrolase, a homolog of the vertebrate neural specific L1 type (Wilkinson et al., 1989).

It should be emphasized that our experiments with extracts of the entire nervous system do not address the special changes that must occur in sensory neurons, the sites of synaptic plasticity. Our analyses do suggest, however, that the activity of at least one crucial component of the Ub pathway, the proteasome, can be modulated. An important feature of the downregulation of $\mathrm{R}$ subunits in sensory neurons is that degradation in vivo is not complete (Greenberg et al., 1987; Bergold et al., 1990). Even though limited, the decrease in $\mathrm{R}$ to $\mathrm{C}$ ratio is sufficient to produce a persistently activated kinase (Sweatt and Kandel, 1989). Limited degradation would be expected if the downregulation is to serve as a physiological control mechanism, since total disappearance of $\mathrm{R}$ subunits would result in totally unregulated protein phosphorylation (Schwartz and Greenberg, 1989). We therefore believe that other steps in the pathway must be regu- 


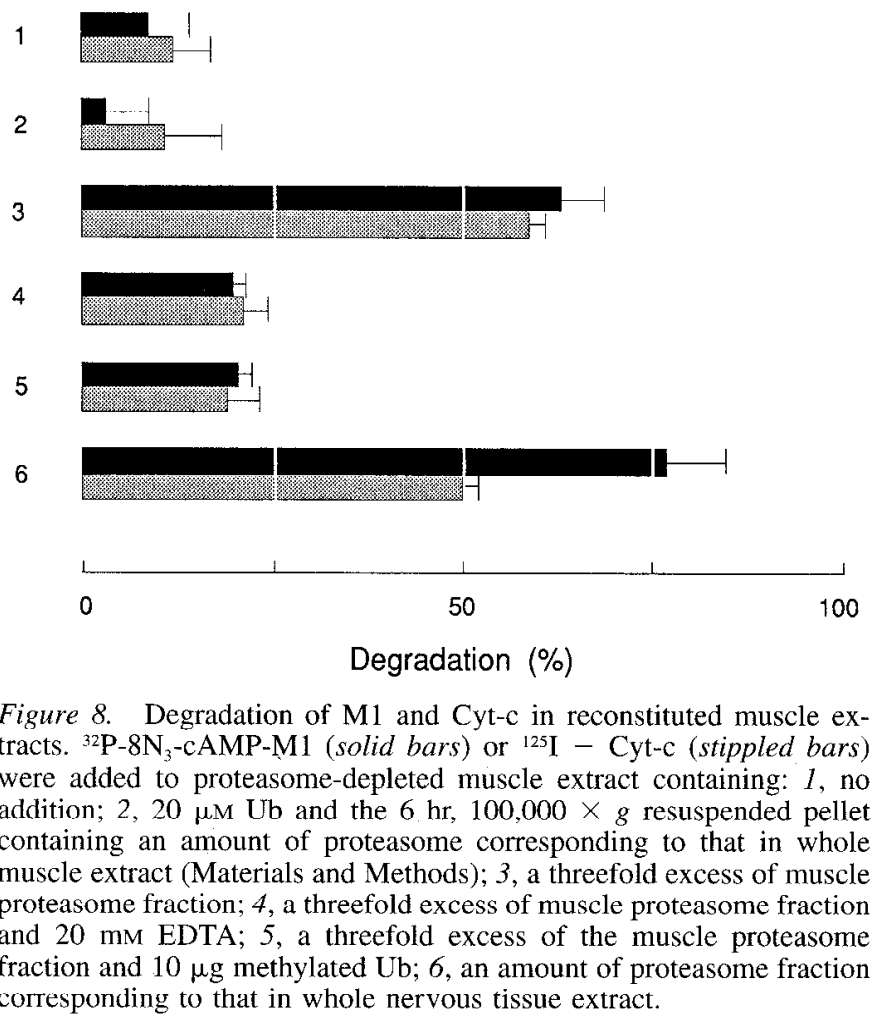

lated. An attractive possibility would be the induction of a specific thioester cascade (Scheffner et al., 1995) involving conjugases (E2) or a targeting factor (E3) for R subunits (Jentsch, 1992; Ciechanover and Schwartz, 1994). Muralidhar and Thomas (1993) and Oh et al. (1994) showed that the Drosophila ben gene encodes a neuron-specific type of Ub-conjugating enzyme that usually requires auxiliary targeting proteins to interact with specific substrates (Sharon et al., 1991). Ben had been shown to be important in neural development including establishing synaptic connectivity (Thomas and Wyman, 1982, 1984). We have not yet been able to identify a specific E2 or E3 for degrading R in Aplysia nervous tissue. Although little is known about signals targeting natural substrate proteins for degradation, there is good evidence to suggest that recognition of vertebrate $\mathrm{N}-\alpha$-acetylated proteins, such as $\mathrm{R}$ subunits, is mediated by EF1 $\alpha$ (Gonen et al., 1994). It is possible that the Aplysia homolog of $\mathrm{EF} 1 \alpha$, which is induced during long-term facilitation (Inokuchi et al., 1995), could play a role in Ub-mediated proteolysis in sensory neurons. Future experiments with sensitized Aplysia neurons are needed to determine how proteasomes are regulated and whether specific Ub-conjugating enzymes also operate in memory storage.

\section{References}

Ambron RT, Sherbany AA, Schwartz JH (1981) Distribution of membrane glycoproteins among the organelles of a single identified neuron of Aplysia. II. Isolation and characterization of a glycoprotein associated with vesicles. Brain Res 207:33-48.

Bailey CH, Kandel ER (1993) Structural changes accompanying memory storage. Annu Rev Physiol 55:397-426.

Beavo JA, Bechtel PJ, Krebs EG (1974) Preparation of homogeneous cyclic AMP-dependent protein kinase(s) and its subunits from rabbit skeletal muscle. Methods Enzymol 38:299-308.

Bergold PJ, Sweatt JD, Winicov I, Weiss KR, Kandel ER, Schwartz JH (1990) Protein synthesized during acquisition of long-term facilitation is needed for the persistent loss of regulatory subunits of the
Aplysia cAMP-dependent protein kinase. Proc Natl Acad Sci USA 87:3788-3791.

Bergold P, Beushausen SA, Sacktor TC, Cheley S, Bayley H, Schwartz JH (1992) Identification of a regulatory subunit of the CAMP-dependent protein kinase down-regulated in Aplysia sensory neurons during long-term sensitization. Neuron 8:387-392.

Beushausen S, Bergold P, Sturner S, Elste A, Rotenberg V, Schwartz JH, Bayley H (1988) Two catalytic subunits of cAMP-dependent protein kinase generated by alternative RNA splicing are expressed in Aplysia neurons. Neuron 1:853-864.

Bey F, Pereira IS, Coux O, Viegas-Pequignot E, Targa FR, Nothwang IIG,. Dutrillaux B , Scherrer K (1993) The prosomal RNA-binding protein $\mathrm{p} 27 \mathrm{~K}$ is a member of the $\alpha$-type human prosomal gene family. Mol Gen Genet 237:193-205.

Bizzi A, Schaetzle B, Patton A, Gambetti P, Autilio-Gambetti L (1991) Axonal transport of two major components of the ubiquitin system: free ubiquitin and ubiquitin carboxyl-terminal hydrolase PGP 9.5. Brain Res 548:292-299.

Bradford MM (1976) A rapid and sensitive method for the quantitation of microgram quantities of protein utilizing the principle of proteindye binding. Anal Biochem 72:248-254.

Byrne JH, Zwartjes R, Homayouni R, Critz SS, Eskin A (1993) Roles of second messenger pathways in ncuronal plasticity and in learning and memory. Insights gained from Aplysia. Adv Second Messengers Phosphoprotein Res 27:47-108.

Chapman AP, Smith SJ, Rider CC, Beesley PW (1994) Multiple ubiquitin conjugates are present in rat brain synaptic membranes and postsynaptic densities. Neurosci Lett 168:238-242.

Cheley S, Panchal RG, Carr DW, Scott JD, Bayley H (1994) Type II regulatory subunits of cAMP-dependent protein kinase and their binding proteins in the nervous system of Aplysia californica. J Biol Chem 269:2911-2920.

Chin GJ, Shapiro E, Vogel SS, Schwartz JH (1989) Aplysia synaptosomes. I. Preparation, and biochemical and morphological characterization of subcellular membrane fractions. J Neurosci 9:38-49.

Chu-Ping M, Slaughter CA, Martino GN (1992) Purification and characterization of a protein inhibitor of the $20 \mathrm{~S}$ proteasome (macropain). Biochim Biophys Acta 1119:303-311.

Ciechanover A, Schwartz AL (1994) The ubiquitin-mediated proteolytic pathway: mechanisms of recognition of the proteolytic substrate and involvement in the degradation of native cellular proteins. FASEB J 2:182-191.

Ciechanover A, Heller H, Elias S, Haas AL, Hershko A (1980) ATPdependent conjugation of reticulocyte proteins with the polypeptide required for protein degradation. Proc Natl Acad Sci USA 77:13651368.

Clegg GH, Cadd GG, McKnight S (1988) Genetic characterization of a brain-specific form of the type I regulatory subunit of cAMP-dependent protein kinase. Proc Natl Acad Sci USA 85:3703-3707.

Dahlmann B, Kopp F, Khuehn L, Hegerl R, Pfeifer G, Baumeister W (1991) The multicatalytic proteinase (prosome, proteasome): comparison of the eukaryotic and archaebacterial enzyme. Biomed Biochim Acta 50:465-469.

DeMartino GN, Moomaw CR, Zagnito OP, Proske RJ, Chu-Pina M, Afendis SJ, Swaffield JC, Slaughter CA (1994) PA700, an ATPdependent activator of the $20 \mathrm{~S}$ proteasome, is an ATPase containing multiple members of a nucleotide-binding protein family. J Biol Chem 269:20878-29884.

Driscoll J, Frydman J, Goldberg AL (1992) An ATP-stabilized inhibitor of the proteasome is a component of the 1500-kDa ubiquitin conjugate-degrading complex. Proc Natl Acad Sci USA 89:6-4990.

Endo S, Shenolikar S, Eskin A, Zwartjes RE, Byrne JH (1992) Characterization of neuronal protein phosphatases in Aplysia californica. J Neurochem 58:975-982.

Fernandez J, DeMott M, Atherton D, Mische SM (1992) Internal protein sequence analysis: enzymatic digestion for less than 10 micrograms of protein bound to polyvinylidene difluoride or nitrocellulose membranes. Anal Biochem 201:255-264.

Finley D, Chau V (1991) Ubiquitination. Annu Rev Cell Biol 7:2569.

Gaczynkska M, Rock KL, Goldberg AL (1993) $\gamma$-Inteferon and expression of MHC genes regulate peptide hydrolysis by proteasomes. Nature 365:211-212.

Goldberg AL (1992) The mechanism and functions of ATP-dependent proteases in bacterial and animal cells. Eur J Biochem 203:9-23. 
Goldberg AL (1995) Functions of the proteasome: the lysis at the end of the tunnel. Science 268:522-523.

Goldberg AL, Rock KL (1992) Proteolysis, proteasomes and antigen presentation. Nature 357:375-379.

Gonen H, Smith CE, Siegel NR, Kahana C, Merrick WC, Chakraburrity K, Schwartz AL, Ciechanover A (1994) Protein synthesis elongation factor EF-1 alpha is essential for ubiquitin-dependent degradation of certain $\mathrm{N}$ alpha-acetylated proteins and may be substituted for by the bacterial elongation factor FF-Tu. Proc Natl Acad Sci IJSA 91:76487652.

Gray CW, Slaughter CA, De Martino GN (1994) PA28 activator protein forms regulatory caps on proteasome stacked rings. J Mol Biol 236: $7-15$.

Greenberg SM, Castellucci VF, Bayley H, Schwartz JH (1987) A molecular mechanism for long-term sensitization in Aplysia. Nature 329: $62-65$.

Haass C, Kloetzel PM (1989) The Drosophila proteasome undergoes changes in its subunit pattern during development. Exp Cell Res 180: 243-252.

Hadari T, Warms JVB, Rose IA, Hershko A (1992) A ubiquitin C-terminal isopeptidase that acts on polyubiquitin chains. Role in protein degradation. J Biol Chem 267:719-727.

Hegde AN, Goldberg AL, Schwartz JH (1993) Regulatory subunits of the cAMP-dependent protein kinases are degraded after conjugation to ubiquitin: a molecular mechanism underlying long-term synaptic plasticity. Proc Natl Acad Sci USA 90:7436-7440.

Hegde AN, Inokuchi K, Yamamoto N, Chain DG, Kandel ER, Schwartz JH (1994) Regulation of ubiquitin-mediated protein degradation during development of long-term facilitation in Aplysia sensory neurons. Soc Neurosci Abstr 20:1072.

Hershko A, Ciechanover A (1992) The ubiquitin system for protein degradation. Annu Rev Biochem 61:761-807.

Hershko A, Heller H, Elias S, Ciechanover A (1983) Components of ubiquitin-protein ligase system. J Biol Chem 258:8206-8214.

Hershko A, Ganoth D, Sudakin V, Dahan A, Cohen LH, Luca FC, Ruderman JV, Eytan E (1994) Components of a system that ligates cyclin to ubiquitin and their regulation by the protein kinase cdc2. $J$ Biol Chem 269:4940-4964.

Hofmann F, Bechtel PJ, Krebs EG (1977) Concentrations of cyclic AMP-dependent protein kinase subunits in various tissues. J Biol Chem 252:1441-1447.

Hunter WM, Greenwood FC (1962) Preparation of iodine-131 labeled human growth hormone of high specific activity. Nature 194:495496.

Ikai A, Nishigai M, Tanaka K, Ichihara A (1991) Flectron microscopy of $26 \mathrm{~S}$ complex containing $20 \mathrm{~S}$ proteasome. FEBS Lett 292:21-24.

Inokuchi K, Pei W, Kandel ER, Schwartz JH, Hegde AN (1995) AplEFl $\alpha$ : a candidate modulatory factor for ubiquitin-mediated degradation of proteins during development of long-term facilitation in Aplysia sensory neurons. Soc Neurosci Abstr 21:1023.

Jentsch S (1992) The ubiquitin-conjugating system. Annu Rev Genet 26:179-207

Kanayama $H$, Tamura T, Ugai S, Kagawa S, Tanahashi N, Yoshimura T, Tanaka K, Ichihara A (1992) Demonstration that a human $26 \mathrm{~S}$ proteolytic complex conists of a proteasome and multiple associated protein components and hydrolyzes ATP and ubiquitin-ligated proteins by closely linked mechanisms. Eur J Biochem 206:567-578.

Kandel ER, Schwartz JH (1982) Molecular biology of learning: modulation of transmitter release. Science 218:433-443.

Laemmli UK (1970) Cleavage of structural proteins during the assembly of the bacteriophage T4. Nature 227:680-685.

Li XC, Gu MZ, Etlinger JD (1991) Isolation and characterization of a novel endogenous inhibitor of the proteasome. Biochemistry 30: 9709-9715.

Ludeman R, Lerea KM, Etlinger JD (1993) Copurification of casein kinase II with $20 \mathrm{~S}$ proteasomes and phosphorylation of a $30-\mathrm{kDa}$ proteasome subunit. J Biol Chem 268:17413-17417.

Matsudaira P (1987) Sequence from picomole quantities of proteins electroblotted onto polyvinylidene difluoride membranes. J Biol Chem 262:10035-10038.

McKnight GS, Clegg CH, Uhler MD, Chrivia JC, Cadd GG, Correll LA, Otten AD (1988) Analysis of the cAMP-dependent protein kinase system using molecular genctic approaches. Recent Prog Horm Res 44:307-335

Medina R, Wing SS, Kettlehut C, Goldberg AL (1992) Protein metab- olism in diabetes mellitus (Nair KS, ed). Burlington, VT: Smith-Gordon.

Mitch WE, Medina R, Grieber S, May RC, England BK, Price SR Bailey JL, Goldberg AL (1994) Metabolic acidosis stimulates muscle protein degradation by activating the adenosine triphosphate-dependent pathway involving ubiquitin and proteasomes. J Clin Invest 93:2127-2133.

Murakami Y, Matsufuji S, Kameji T, Hayashi S, Igarashi K, Tamura T, Tanaka K, Ichihara A (1992) Ornithine decarboxylase is degraded by the $26 \mathrm{~S}$ proteasome without ubiquitination. Nature 360:597-599.

Muralidhar MG, Thomas JB (1993) The Drosophila bendless gene encodes a neural protein related to ubiquitin-conjugating encymes. Neuron 11:253-266.

O'Farrell PH (1975) High resolution two-dimensional electrophoresis of proteins. J Biol Chem 250:4007-4021.

Oh CE, McMahon R, Benzer S, Tanouye MA (1994) bendless, a Drosophila gene affecting neuronal connectivity, encodes a ubiquitinconjugating enzyme homolog. J Neurosci 14:3166-3179.

Orlowski M (1990) The multicatalytic proteinase complex, a major extralysosomal proteolytic system. Biochemistry 29:10289-10297.

Palazzolo M, Katz F, Kennedy TE, Schwartz JH (1989) Multiple cAMP-binding proteins in Aplysia tissues. J Neurobiol 20:746-761.

Pereira ME, Wilk S (1990) Phosphorylation of the multicatalytic proteinase complex from bovine pituitaries by a copurifying cAMP-dependent protein kinase. Arch Biochem Biophys 283:68-74.

Pickart CM, Rose IA (1985) Functional heterogeneity of ubiquitincarrier proteins. J Biol Chem 260:1573-1581.

Rechsteiner M, Hoffman L, Dubiel W (1993) The multicatalytic and 26S proteases. J Biol Chem 268:6065-6068.

Rogers S, Wells R, Rechsteiner M (1986) Amino acid sequences common to rapidly degraded proteins: the PEST hypothesis. Science 234: 364-368.

Sambrook J, Fritsch EF, Maniatis T (1989) Molecular cloning: a laboratory manual, 2nd ed, pp 1.25-1.28. Cold Spring Harbor, NY: Cold Spring Harbor Laboratory.

Savedia S, Kiernan JA (1994) Increased production of ubiquitin mRNA in motor neurons after axotomy. Neuropathol Appl Neurobiol 20: 577-586.

Scheffner M, Nuber IJ, Huibregtse IM (1995) Protein ubiquitination involving an E1-E2-E3 enzyme ubiquitin thioester cascade. Nature 373:81-83.

Schwartz JH, Grecnberg SM (1989) Turtles all the way down: some molecular mechanisms underlying long-term sensitization in Aplysia nervous tissue. In: Neural models of plasticity (Byrne J, Berry R, eds), pp 46-57. New York: Academic.

Schwartz JH, Swanson ME (1987) Dissection of tissues for characterizing nucleic acids from Aplysia: isolation of the structural gene encoding calmodulin. Methods Enzymol 139:277-290.

Sharon G, Raboy B, Parag. HA, Dimitrikovsky D, Kulka RG (1991) RAD6 gene product of Saccharomyces cerevisiae requires a putative ubiquitin protein ligase (E3) for the ubiquitination of certain proteins. J Biol Chem 266:15890-15894.

Sokolik CW, Cohen RE (1991) The structures of ubiquitin conjugates of yeast Iso-2-cytochrome c. J Biol Chem 266:9100-9107.

Sweatt JD, Kandel ER (1989) Persistent and transcriptionally-dependent increase in protein phosphoryletion upon long-term facilitation in Aplysia sensory neurons. Nature 339:51-54.

Tanaka KJ, Yoshimura T, Ichihara A, Ikai K, Nishigai M, Morimoto Y, Sato M, Tanaka N, Katsube Y, Kameyama K, Takagi T (1988) Molecular organization of a high molecular weight multi-protease complex from rat liver. J Mol Biol 203:985-996.

Taylor S, Buechler JA, Yonemoto W (1990) cAMP-dependent protein kinase: framework for a diverse family of regulatory enzymes. Annu Rev Biochem 59:971-1005.

Thomas JB, Wyman RJ (1982) A mutation in Drosophila alters normal connectivity between two identified neurones. Nature 298:650-651.

Thomas JB, Wyman RJ (1984) Mutations altering synaptic connectivity between identified neurons in Drosophila. J Neurosci 4:530-538.

Towbin H, Staehelin T, Gordon J (1979) Electrophoretic transfer of proteins from polyacrylamide gels to nitrocellulose sheets: procedure and some applications. Proc Natl Acad Sci USA 76:4350-4354.

Tsubuki S, Kawasaki H, Saito Y, Myashita N, Inomata M, Kawashima S (1993) Purification and characterization of a Z-leu-leu-leu-MCA degrading protease expected to regulate neurite formation: a novel 
catalytic activity in the proteasome. Biochem Biophys Res Commun 15:1195-1201.

Weber W, Vogel C-W, Hilz H (1979) A new cAMP affinity matrix for the rapid purification of protein kinase regulatory subunits. FEBS Lett 99:62-66

Wilkinson KD (1990) Detection and inhibition of ubiquitin-dependent proteolysis. Methods Enzymol 185:387-397.
Wilkinson KD, Lee KM, Deshpande S, Duerksen-Hughes P, Boss JM, Pohl J (1989) The neuron-specific protein PGP 9.5 is a ubiquitin carboxyl-terminal hydrolase. Science 246:670-673.

Yoshimura T, Kameyama K, Takagi T, Ikai A, Tokunaga F, Koide T, Tanahashi N, Tamura T, Cejka Z, Baumeister W, Tanaka K, Ichihara A (1993) Molecular characterization of the " $26 \mathrm{~S}$ " proteasome complex from rat liver. J Struct Biol 111:200-211. 